\title{
8. Professionalising Corruption? Investigating professional ethics for politicians
}

\author{
John Uhr
}

In this chapter, I try to open up a new perspective on professional ethics as applied to elected politicians by exploring two questions. First, given that the main goal is to improve the state of political ethics, is a professional-ethics model the best way to proceed? I answer with a very qualified 'yes', arguing that democracy needs real ethics, not the empty formalism sometimes found in professional-ethics schemes. My answer draws on J. M. Coetzee's novel Elizabeth Costello (2003, pp. 284-7), a fascinating recent account of the limits of professional ethics. ${ }^{1}$

Second, how can real ethics affect real politics to strengthen democratic practices of self-government? My answer distinguishes between two overlapping policy preoccupations: one interested in external accountability to combat unethical politics, particularly political corruption; and another interested in internal responsibility to promote ethical politics, especially ethical political leadership. Here my attempt is to take the 'ethics' in 'political ethics' seriously, in order to contribute to the debate over ethical politics - not simply political ethics.

What passes as political ethics is itself a political issue, best determined through political processes that give the public opportunities to weigh up contending views about the prudence and good sense of questionable political conductthe view endorsed by the Canadian Senate Ethics Officer (2009-10, p. 12). Open, deliberative processes can allow politicians to account for and justify the public value of suspect conduct-before other politicians and before the public. Prudence is more valuable than prescription, although prescribed structures of public deliberation can bring prudence to the fore if used responsibly by politicians. Ultimately, that is a question for the public to judge.

I am sketching a regulative ideal rather than a regulatory mechanism. The ideal trusts politicians to reward decent and honourable conduct and to punish unethical conduct. How they do that is best for them to judge, according to the constitutional conventions of each political system. My preference for deliberative structures is consistent with many of the checks and balances

1 Parts of the novel were published in Coetzee (1999, pp. 15-69) along with several responses (pp. $73 \mathrm{ff}$ ). For further discussion, see Leist \& Singer (2010). 
common to liberal constitutionalism; and even if the regulative ideal is never matched in political practice, at least it gives politicians a fair sense of the standards of political ethics that we as a democratic political community might want of them.

\section{The issue of responsibilities}

My argument is in two parts. The first part reduces the prominence of 'professional' in the style of professional ethics we might expect of politicians. The aim here is to clear a space for what I am tempted to call 'real ethics' by reducing the domination of professional or role ethics. The second part builds on this proposal. It widens the scope of the political in political ethics to include recognition, and even encouragement, of decent political ethics and aims to balance the prevailing focus on indecent or corrupt political ethics.

And what might encourage ethical political decency? Drawing on principles of deliberative democracy, including those examined in my Deliberative democracy in Australia (Uhr, 1998), my answer is that public political deliberation can encourage political decency. How can public deliberation strengthen political decency? By allowing all parties to governance relationships to have their say on the state of their official responsibilities, thereby providing the public - should it be in a position to listen - with opportunities to review standards of political responsibility.

Much turns on these two concepts of 'responsibility' and 'relationship', clarified below. The two parts of my argument work together to support my contention that democracy has more to gain by trusting politicians to take greater (but not by any means total) responsibility for regulating their own ethics than by distrusting politicians and subjecting them to regulation, primarily through external anti-corruption commissions.

The term 'politicians' covers a diverse class of public actors. My scheme presumes that this very diversity can encourage a proactive system of checks and balances where non-executive politicians (including legislators, backbenchers and the opposition) use the publicity of deliberative processes to keep those with greater political power (such as heads of government or cabinet ministers) 'responsible' in the conduct of their official relationships (ministers with civil servants, for example). The hope is that structures of public deliberation would enable politicians with 'professional' capacities to be trusted to regulate much of their own public conduct.

The case against professional ethics faces two prominent claims, amongst many others. Most basically, there is the theoretical claim that the full nature 
of ethical conduct cannot be reduced to the forms appropriate to professional conduct, despite the welcome public benefits of properly managed professional conduct. Ever since Bradley (1962 [1876]) explored the ethic of 'my station and its duties', the ethics of office or role have won at best only qualified praiseeven from Bradley himself, who was more interested in social than vocational roles. Yet many aspects of his approach escaped the attention of his early critics like Sidgwick (1967, pp. 284-7). Second, there is the practical claim that forms of self-regulation typical of professional ethics are plagued by practical defects deriving from the capture of the regulatory system by the professions. Contaminating private interests too often weaken the promised public benefits. If we take these two claims into account, political occupations provide one of the hardest test cases for advocates of professional ethics, who face considerable odds in persuading critics that either or both of these two counterclaims can be overcome.

While I acknowledge the force of the general case against professional ethics, I want to sketch the principles of a version of professional self-regulation that is suitable to democratic politics. One test of professionalism is the capacity for self-regulation of official conduct. I favour models of political ethics that include opportunities for politicians to take greater responsibility to regulate their own conduct. But this preference is unrelated to any political professionalism. The reverse is more likely: politics being a public rather than simply a professional activity, decisions about what constitutes appropriate political conduct are matters for public debate. Politicians can help or hinder that process but they should not be excluded from it for fear about conflicts of interest. Conflicts of interest can and do arise, and abuse of office has to be regulated. But there can be conflicts of responsibility as well as conflicts of interest, where competing ethics of political responsibility clash.

The most dramatic example from recent Australian experience comes from President George W. Bush's 2003 visit to the Australian Parliament, where his address was interrupted by the two Greens senators who later refused to vacate the chamber when so directed by the presiding officer. The government successfully moved to exclude the two Greens senators from the next day's joint session with the Chinese President. Both incidents - the senators' conduct in interrupting President Bush and the government's excluding them from the subsequent parliamentary meeting with the Chinese Presidentignited considerable public debate over who should have the political power to determine how elected representatives conduct themselves when engaged in parliamentary business. At one extreme was support for the right of every elected representative to make their own decision on when and where to speak out on issues of public concern-including, if they are prepared to stand by their judgment, interrupting an address to the national parliament by the US 
President. At the other extreme was support for the decision of the Howard Government that there should be no repeat of any such allegedly irresponsible conduct - particularly at a time when Australia was about to sign an important energy contract with China.

These extremes reflect contrasting norms of political responsibility, with no hint that either is tainted by suspicion of illegality or corruption. But the lively community debate over these contrasting ethical postures tells us much about the neglected end of political ethics: democratic communities are surprisingly keen to talk through the political ethics of self-government when confronted with contrasting examples of responsible ethical judgment by politicians. My point is not to award ethical points for exemplary decency to either position but to call attention to the larger issue of process: democratic political ethics are tested through public deliberation over the responsibilities of debatable political conduct. This deliberation occurs in relation to contrasting models of political decency, no less than in relation to models of corruption. Frequently this does not involve any issue of self-interested abuse of office but rather is a clash of ethical expectations about the proper use of political office or about standards of political decency. Debate over failures by politicians to do the right thing (such as failure to listen in silence to a visiting head of government or failure to allow elected representatives their right to join other parliamentarians in a meeting with a visiting head of government) can be just as central to public life as debate over alleged criminal misconduct by politicians.

\section{Ethics or corruption?}

My point of departure is that it is misleading to treat political ethics solely with the analytical tools used to deal with political corruption. Large parts of the 'ethics' in political ethics go un-investigated when the methods of corruption analysis dominate the scene. To exaggerate for effect: 'ethics' itself is corrupted when the focus is on the negative effects of corrupt conduct with little or no interest in the positive effects of ethical conduct. For those who like big concepts: this analytical 'corruption' limits our access to the phenomenologyor full range of characteristic conduct - captured by the category of "political ethics'. Missing from most accounts are the phenomena at the ethical end of political ethics. One useful example of neglected practice is the investigation of types of exemplary public conduct in the Cooper and Wright reader Exemplary public administrators (1992).

Importing a distinction I defend at greater length in Terms of trust (Uhr, 2005, particularly pp. 197-204), I distinguish studies of political ethics from studies of political corruption by reference to the public conduct they seek 
to explain. Put crudely: corruption analysis explains how different forms of external accountability (that is, external to the politicians concerned) impede political corruption, and ethics analysis explains how different forms of internal responsibility (that is, internal to the politicians concerned) promote political ethics. Those familiar with the old Friedrich-Finer debate in US public administration will recognise this distinction as derivative from that influential exchange over the contest of the two values of accountability and responsibility - values that are distinguishable even if in practice they are inseparable.

The topic of 'political ethics' covers two poles of conduct: the unethical pole with the tension between corruption and its detection through public accountability; and the ethical pole with the tension between ethics and its discovery through personal responsibility. I want to distinguish the study of political ethics from the study of political corruption - the latter usually understood as a form of criminal misconduct best regulated by non-politicians. Investigation of political ethics gets at other forms of abuse of office: conduct that is not illegal but not necessarily right or decent. I argue that democratic standards of ethical political conduct are matters for political debate and determination, ideally (nice word!) managed politically through processes of political argument and public deliberation.

\section{The issue of relationships}

My take on professional political ethics will focus on the ethics of official relationships. Ethically responsible conduct by democratic politicians is largely about their management of official relationships. Other approaches deal with conflicts of interest or with outright corruption. My worry is that many aspects of what we might call 'constitutional morality' go unnoticed in these approaches. Of particular concern is the lack of scholarly attention to the ethical responsibility politicians have for managing relationships amongst the various institutions of government. To the extent that politicians have 'professional' duties, I think these duties derive from their share in the collective responsibility for the appropriate public use of political power. As I describe a little later, different political offices will have different types of responsibilities, depending on the specific powers at their disposal (legislative, executive, head of government, member of cabinet, senior advisor, civil service, military service, and so on). As responsibilities change, so do the specific institutional relationships necessary to give effect to the public powers in question. The ethics of institutional relationships might be less tidy than the ethics of personal power, but they are the building blocks of any 'profession' of public responsibility suitable to a democratic society (Uhr, 2010a). 
To simplify: ethical responsibility is tested in judgments about the management of political relationships. My suggested distinction between political ethics and ethical politics can help keep the focus on ethical relationships. By 'political ethics', I am referring to the political conventions for managing disputes over ethical conduct through rules and regulations over the fine lines between private interest and public duty. This is what is usually meant by ethical regulation of political conduct, the aim being to reduce the incidence of private use of public office. The conventional approach moves along a path of distrust and is based on assumptions that politicians generally cannot be trusted with the responsibility of regulating their own ethical conduct. Relevant policy prescriptions include peer investigation but increasingly focus on external regulation of political conduct by ethics or integrity commissions and the like. By contrast, 'ethical politics' builds on trust rather distrust, conferring a kind of professional autonomy on politicians to manage their own power relationships through a framework with considerable self-regulation. Here the aim is not the negative one of reducing the incidence of the vices associated with the private use of public office but the more positive one of stimulating the virtues associated with praiseworthy political management of official relationships of power.

Politicians cannot be expected not to be political. It makes good policy sense to take precautions against unethical forms of political conduct. The path of distrust leads to greater and greater public accountability of politicians, with many external accountability agencies holding the line against formal breaches of ethical rules and expectations. But it also makes good policy sense to try to promote higher forms of ethical political conduct, beyond simple compliance with the rules. This alternative path of trust opens up possibilities for more substantial ethical responsibility, in the quite traditional sense represented by the political virtue of prudence as the driver of ethical responsibility in public life. In its most expansive sense, being ethical for politicians means acting prudently - taking prudence to mean the political virtue of practical wisdom so necessary for the sound management of official relationships. Actions speak louder than words, and political actions that build relationships can be more effective in promoting ethical politics than any number of fine words in a formal code of conduct. For example, the prudent decision by former UK Prime Minister Tony Blair to appear before the House of Commons Liaison Committee twice a year had probably greater potential power to improve the tone for British parliamentary conduct (should both sides in this relationship be willing) than any set of revisions to the Commons' code of conduct.

Now I admit that it stretches belief to suggest that the use and abuse of political prudence lend themselves to professional self-regulation. Prudence thus understood is not only the exercise of judgment but it is the exercise of political judgment in managing official relationships. Matters of judgment attract 
debate over the use and abuse of discretion; and matters of political judgment attract debate over the use and abuse of political deliberation by parties to the decisions in dispute. But this very recognition of prudential deliberation through open political debate highlights the nature of the professional standard invoked when speaking of professional ethics for democratic politicians. The model of professionalism here is not that of the single provider responsible for professional services but that of an assembly sharing responsibility for the provision of professional services. That, at least, is the ideal.

\section{But is politics a profession?}

But does the ideal match our realities? The case for treating politicians as a profession deserving the public trust associated with self-regulatory professional responsibilities seems far-fetched, at least initially. Across the democratic world, politicians universally lack the public confidence of professionals like health professionals, legal professionals, teachers, many police forces and the military. This lack of public confidence reflects widespread suspicion that politicians lack the capacity for responsible self-regulation of their professional conduct.

For all I know, this suspicion might be well founded. After all, politics is an occupation open to all comers with no easily discernable professional training that might qualify would-be politicians for political practice. The best-known case for treating 'politics as a vocation' - that presented by Max Webercertainly had an ethical theme, and related writings by Weber highlight the importance of supervised experience and career training in the development of political leaders (Weber, 1994 [1919]). But remember the nature of this ethical theme: politics can be treated as 'a vocation' because of the distinctive calling seen in the practice of truly great political leaders who are prepared to live for and not simply off politics. These exceptional public figures not only break the rules but also break the mould of conventional political ethics. They take personal responsibility for their own political conduct and are prepared to be judged by the consequences of their own decisions. By taking responsibility, they are not simply 'taking charge' but also, in democratic systems, preparing to face up to a wider public reckoning of their political ethics.

Weber's approach is less an argument for professionalism and more one for exceptionalism: political ethics are exceptions to the normal ethical rules. This argument is one of the most influential in favour of a kind of ethical autonomy for politics. But it is an argument that seems to concede too much autonomy, sheltering irresponsible schemers beneath the scaffolding intended for responsible leaders. Weber's ethic is compatible with the 'dirty hands' ethic, which, certainly in the time since Weber, has been reformulated to justify everything from the 
grand exceptionalism of a 'capital $\mathrm{M}^{\prime}$ Machiavellian leader to the corrupt conduct of many 'small $\mathrm{m}$ ' machiavellian schemers. What holds for leaders does not necessarily hold for schemers. This schemer-stealth is a classic example of what gives professional ethics a bad name. Norms of appropriateness devised to apply to distinct and distinguished practitioners are seized on by indistinct and undistinguished competitors. The danger is that any public benefit accruing to professional claims of ethical exceptionalism will be jeopardised by the private benefits of the professional pretenders. Most professional associations granted self-regulatory powers strive to justify their due diligence in policing their own professional ethics. Once again, politics is exceptional, in that there are so few examples to reassure a suspicious public that politicians deserve to be granted authority to regulate their own affairs. Periodic stories of corruption are enough to drive out the high hopes for ethically responsible politics.

The dismal record of political self-regulation is one important practical count against political professionalism. Another is the deeper theoretical reservation about the ethical integrity of professional or role ethics. One of the most striking examples of the critique of professional ethics in public life comes from the novel Elizabeth Costello (2003) by the 2003 Nobel Prize winner for literature, J. M. Coetzee. His novel contains a dramatic illustration of the merits and pitfalls of professional or role ethics. Within limits, I support a professional approach to the regulation of politicians' ethical conduct, one that confers considerable responsibility on elected or representative politicians to take the initiative in managing the resolution of conflict over alleged breaches of appropriate standards of ethical conduct. The relevance of Coetzee's novel is that it helps clarify what I mean by 'within limits'.

The novel draws attention to the limits of attempts to reduce ethics to role compliance, and implicitly to the dangers of professions' claims of ethical exceptionalism. At the end of the day, being ethical means doing the right thing, regardless of what one's profession deems to be right according to the professional role. In the case of politicians, being ethical is more than simply not breaching the rules of official conduct or even obtaining formal clearance from an ethics committee of one's peers. Weber, to his credit, knew this and made the test of ethical responsibility a demanding version of consequentialism: having the courage to stand firm, taking personal responsibility for non-compliance with the unconditional obligations of conventional orthodoxies and being prepared to justify the public benefits of one's deviation from conventional norms. 


\section{Rethinking the ethical in professional ethics}

The novel Elizabeth Costello is subtitled 'Eight lessons', with the eight substantive chapters each tackling a particular 'lesson'. Elizabeth Costello is an imaginary Australian writer, who, in her older years, becomes the invited celebrity at many literary and academic conferences. She knows that her celebrity reflects her early work, not her present writing, and that these invitations cannot last. In some ways, the end of these invitations would be a blessed relief, as she would be released from the obligation of having to explain herself and her work-a task she finds increasingly difficult as she ages and weighs the merits of her earlier work, and becomes increasingly aware of the better work that she has never completed. Much of the novel deals with this tension between the public persona of 'the author' and the private character of the writer who is more and more detached from her prominent role as celebrity author. Tired of making public statements, Elizabeth Costello retreats into a private world where she permits greater honesty about her self and her talents as a writer and person.

The topic of professional ethics appears in the last lesson, entitled 'At the gate', when Elizabeth is called on to account for her moral beliefs, encountering her final act of public scrutiny 'at the gate' of heaven-Coetzee never uses this traditional term for the resting place of the good (compare with Funk \& Palm, 2010, pp. 193-225). In fact, it is probable that Coetzee is not writing about the afterlife of Elizabeth Costello at all, but is letting the reader see how she anticipates this prospect well before her death. The publication of yet another Elizabeth Costello story after the publication of the novel supports this interpretation (Coetzee, 2004, 2005, chs 13-20, especially pp. 27-30). Not that Coetzee makes things easy for readers. What Coetzee says of Philip Roth applies equally to himself: readers must struggle with the author's 'long-running practice of complicating the line of transmission along which the story reaches the reader and putting in question the mediator's angle on it', such that readers are bound to be 'dominated by uncertainty about how far the narrator is to be believed' (2010).

Back, then, to Elizabeth's imaginary anticipation of her final rite of passage. Arriving at the gates by bus (we are not alone even in this, the final journey), Elizabeth asks permission to pass through the closed gate separating heaven from the world of the still-restless souls. But the authorities ('the guardians') tell her that before she can enter, she 'must make a statement' (p. 193). Will this posturing never end, she thinks; why can't I simply pass through the gate and put paid to my earthly debt? Handed a blank piece of paper, Elizabeth is told that the required statement is to be a statement of 'what you believe' (p. 194). As 
the burden of this 'trial' begins to dawn on her, Elizabeth realises that 'before she will be found good' she must do what she can to provide evidence of her goodness in her beliefs.

Can her beliefs carry this burden? Elizabeth protests that as a writer, 'it is not my profession to believe, just to write. Not my business. I do imitations, as Aristotle would have said' (p. 194). Then she begins a slippery process of plea-bargaining: 'I can do an imitation of belief, if you like' (p. 194). She gets no encouragement. She later regrets 'this tendency to flare up' (p. 203), which reflects her conviction that she is typically misunderstood and that she deserves better. She is a true professional and wants to be appreciated as a model of a professional writer. Generally, she resists inquiries into her inner world of personal interest and deflects attention back to the external world of her professional capacity.

Now taking an even more radical turn, Elizabeth writes a statement of belief to challenge the rule about statements of belief. Understanding herself as a writer who trades in fictions, she records that she maintains beliefs 'only provisionally: fixed beliefs will stand in my way' (p. 195). So on these grounds - which she calls 'professional, vocational' - Elizabeth requests 'exemption from a rule' requiring every petitioner to 'hold one or more beliefs' (p. 195). Her strategy is unsuccessful. The guardian figure tries to encourage her with an incentive. He allows her a brief glimpse of the brilliant light through the open gate; then, in a 'surprisingly personal' gesture, he acts out of keeping with his own professional role and pats her on the arm, inviting her to 'try harder' (p. 196). Forgetting herself or her place, Elizabeth tries to behave smarter rather than harder. She begins to joke with the guard, but to no avail. Humour works no better than serious pleas for exemption, so she accepts that she had better return to the task at hand and prepare the required statement of beliefs.

Elizabeth takes stock of her situation and returns to this, the most difficult act of writing she has ever attempted. Eventually, she completes the statement to her satisfaction and her day in court arrives. Elizabeth is called before the court of nine 'male and elderly' judges to present her statement (p. 198). She begins reading her statement, explaining why writers have no beliefs. Her thesis is simple: 'my calling: dictation secretary' (p. 199). Later she identifies this as 'a secretary's way of life', their special vocation being to record but not to judge the worth of what they hear (p. 204). Claiming that as a writer it is not her role 'to interrogate' or 'to judge' the beliefs of those about whom she writes, Elizabeth says that 'what I write is what I hear', not what people might want to hear (p. 199). As a 'good secretary', the writer 'should have no beliefs (p. 200). It is 'inappropriate to the function' (p. 200). Her rather compelling argument is that personal beliefs act as obstacles to writers, resisting their capacity to hear properly what others say and believe. 
The response is not long coming. Says one judge: 'Without beliefs we are not human' (p. 200). Elizabeth's response is that her 'sense of duty' follows her 'function', with the result that 'I have beliefs but I do not believe in them' ( $\mathrm{p}$. 200). The next response is quick and acute: what effect, the judge asks, does this 'lack of belief' have on 'your humanity?' (p. 201). Elizabeth protests that her own humanity is of no consequence, claiming that her 'own emptiness' is outweighed by her contribution as a writer to the humanity of her readers ( $\mathrm{p}$. 201). For 'professional reasons', Elizabeth cannot afford to believe: she 'cannot afford to take myself too seriously' (p. 201). She begins to appreciate that this must sound as though she is treating the court proceedings with contempt.

At this point a judicial voice asks: 'And what of the Tasmanians?' (p. 202). What might appear an obtuse aside is in fact a confronting move intended to tease out whether this Australian writer really has 'no beliefs to guide her' in thinking about the miserable fate of the Indigenous Tasmanians - exterminated, Elizabeth now recognises to herself, by 'her countrymen, her ancestors' (pp. 201-2). A judge asks why Elizabeth presents herself 'not in your own person but as a special case, a special destiny, a writer' (p. 203). Forcefully, the judge asks if being a professional secretary means that one makes no judgments and is therefore 'bankrupt of conscience?' (p. 204). Elizabeth now knows that she is 'cornered', beaten down by what appears to be 'a contest of rhetoric' rather than a real interrogation into truth (p. 204). Weighed under by too many 'heady abstractions', Elizabeth departs the hearing with a severe headache, knowing that she has lost her case (p. 205).

Eventually she gets a second chance. She is now aware that her problem is that she 'cannot afford to believe' because in her 'line of work one has to suspend belief' (p. 213). Despite this, Elizabeth gets her second hearing, this time before a new panel of judges, smaller than the first one and now including a female judge. She takes advice from another petitioner and presents a case illustrating her passion rather than her beliefs. It is a riveting performance, an exemplary apologia of her life history, presented 'not as a writer but as an old woman... telling you what I remember' (p. 217). Passing over her remarkable presentation about her memories of her childhood in rural Victoria and her relish for the natural environment, I simply note that the judges are confused. Is Elizabeth replacing her former plea with its absence of beliefs with a new one based on explicit beliefs? Or are her recollections of her passionate life evidence of a very human belief in life? Elizabeth's desperately truthful answers to their many questions are attempts to defend the integrity of both of her two formal statements of belief. But this is of little avail, finally provoking the judges to 'howl with laughter' at this picture of strained personal integrity (p. 221). 
Elizabeth recognises that 'the special fidelities' of her vocation will not allow her win this final rite of passage (p. 224; compare with Lodge, 2003; Wood, 2003).

Coetzee does not allow us to see any further into Elizabeth Costello's final saga. As I suggested, the saga may well be all in Elizabeth's mind, a kind of mental rehearsal for the real thing. But given Coetzee's artistry, the power of her passion is no less real for the readers of Elizabeth Costello. The lesson ends where it began, with Elizabeth restlessly wondering just what it takes to get through the gates to the peace on the other side. Elizabeth ponders her new knowledge of the cost of her own loyalties to her vocation, appreciating that fidelity is 'the word on which all hinges' (p. 224). At least she has learnt that her pride in her professionalism does not, in the end, count for much in the eyes of her gatekeepers. The advice to try the path of passion is useful because it brings out more of her own personal beliefs, even if Elizabeth is ill prepared to explain their meaning. Her tendency to slip back into her professional mode of nonevaluative recording probably shows that the early passion has faded, at a cost only now beginning to be appreciated in the afterlife of this gifted writer.

Where does this leave us? Elizabeth Costello presents herself very much as an individual but for our limited purposes, which do less than justice to Coetzee's own purposes, she can stand as an example of a professional type: indeed, the type of a professional. Professions do differ and not all have the same degree of impersonality that the writer Costello thinks appropriate to her calling. But this studious impersonality with its restraints on partiality of judgment in the business of storytelling causes us to wonder about the parallels with other professions. In general, the ethics of professionalism are variations on this theme of impersonality. Professional ethics tell practitioners to carry out their duties informed by their professional, as distinct from their personal, judgments about the responsible course of conduct in the circumstances. This point highlights rather than minimises the role of discretionary judgment in professional practice, but according to a demanding model of discretion with little or no place for personal value judgment. For good reasons, practice is never as tidy as this impersonal model: the best professionals tend to be good human beings as well as good professional practitioners. In the context of his novel, Coetzee invites us to ask if the judges are so blind that they cannot see that Elizabeth Costello is a good person as well as a good writer. Perhaps they are the models of professional limitation, so blinded by their adherence to form that they fail to give Elizabeth her due justice. 


\section{Rethinking the political in political ethics}

I move now from my reorientation to ethics to my reorientation to politics. The first move attempted to widen the scope of appropriate ethical conduct to include the positive pole of the decent as well as the negative pole of the dishonest. Of course, broadening the category of researchable conduct does nothing to increase the incidence of decent conduct. Broadening the category simply opens up the possibility of fresh research into debates over decency to balance the prevailing preoccupation with debates over dishonesty. Decency typically begins with compliance with the rules, but there is plenty of scope for debate over the supra-legal expectations of appropriate political conduct. To my mind, this is as much a political as an ethical question - in fact, an ethicopolitical question.

The second move reinforces the turn from political ethics generally to ethical politics more specifically. If democracy is the basic political norm under consideration then the study of ethical politics is going to involve investigation of a democratic ethic of shared responsibility for self-government. What orientation to 'the political' would be compatible with this new research impetus? My suggestion is drawn from theories of deliberative democracy because of their attention to the importance of norms of responsible political argument in structuring democratic politics. To say that decency or ethical responsibility amongst politicians is an ethico-political question is to say that standards of appropriate conduct are, in a democracy, ideally determined through responsible public deliberation over the forms and substance of ethical politics. This proposition allows for a considerable contribution by politicians, through open and accountable systems of self-regulation of suspect or debated instances of political conduct. While the standards of appropriate conduct might be thought to belong to the democracy itself, responsibility for detailed management of claims and counterclaims over suspect conduct rests with serving politicians, in keeping with their public responsibilities as representatives of the political community.

What are the institutional implications of this preliminary conclusion? To me, the most important principle is that 'professional political ethics' makes sense only if we recognise the collective character of political professionalism. Think of this, if you want, as a version of the 'many hands' thesis: that political responsibility is shared responsibility-between electors and the elected, between executive and legislative officials, between political branches and the judiciary, between cabinet ministers and the bureaucracy, between insiders and outsiders, and so on. In keeping with the many hands thesis, politicians can evade ethical responsibility by claiming that others took a greater role in instances of debatable conduct. But there is another dimension to this collective 
arrangement sometimes neglected in the many hands literature. It is the other side of the evasion story: political ethics is not so much about individual conduct as about shared responsibility for the conduct of relationships. If we put to one side the conventional approach to criminal misconduct through abuse of office, there is still plenty to investigate in the legal-but-questionable conduct by politicians in the use and abuse of relationships of public power. Westminsterderived parliamentary systems provide many examples: in the ways that prime ministers dominate relationships with cabinets, ministers dominate relationships with civil servants, ministerial consultants dominate relationships with both ministers and civil servants, higher civil servants dominate relationships with lower civil servants, who in turn dominate service providers, who in turn dominate consumers of public services. I emphasise 'domination' to bring out the incompatibility of these sort of power relationships with democratic norms. This recital of dominating relationships is a caricature but it conveys the message: political ethics is about many things, not least the conduct of those official relationships amongst public institutions that 'constitute' the political and policy process. The study of political ethics deals with the state of relationships amongst the many political offices sharing political power, including the basic organising offices of citizen and government. Thus, political ethics includes the study of the norms that constitute democracy as evident in the political management of governance relationships.

A final institutional consequence to note here is that political relationships are relationships of mutuality. Political ethics cannot be gauged solely through investigation into one party to the relationship. Indeed, whole webs of relationships influence the political conduct of individual political actors. The institutional implication is that political ethics should include the study of the conduct of public processes and not just the study of the conduct of individual actors. To give but one illustration: parliamentary systems typically have codes of ministerial conduct, occasionally even including independent advisors on ethics and integrity. Within limits, these codes of conduct can help clarify expected standards of official conduct by ministers. But in almost all instances, the codes are creatures of the political executive, illustrating a very circumscribed relationship within the holders of executive power. When push comes to shove, the professed standards of high responsibility are overridden by the operational norms of executive convenience.

The Australian story is one of prime ministerial discretion to interpret ministerial conduct in the light of the political interests of the serving government. The relationship does not include the wider body of elected representatives, despite the constitutional rhetoric of responsible parliamentary government. Elsewhere I have argued that parliament has only itself to blame because it has failed to deal itself in by establishing or instituting a relationship with ministers whereby 
they agree to honour parliamentary as distinct from ministerial standards of public conduct (Uhr, 2010b, pp. 124-9). This failure also means that parliament has failed in its relationship with electors by not living up to its responsibilities as an accountability agency that protects the public interest in open and honest government.

\section{Ethics by example}

I can try to bring this together with an Australian example: the so-called 'children overboard' affair in the lead-up to the 2001 national election. This example balances my earlier use of Coetzee's novel with an account of Australian lapses in political decency that reads all too much like a novel. If only the events described were fictional.

There is a growing academic literature on the political and administrative ethics surrounding these events, most of which suggests that the re-election of the Howard Government came at the price of unprecedented damage to the government's reputation for public integrity. The government won the election and, not surprisingly, defended its integrity in terms of having earned the public mandate to retain the responsibilities of executive power. It defended its ethical credentials by pointing to the balance between its right to use the responsibilities of governmental power as it saw fit (acknowledging that this right is subject to the limits of the law) and its proven public accountability as evidenced by its electoral victory. From the government's point of view, no law was broken during its tenure in office and the people had spoken, giving fresh legitimacy to the governing Coalition. In this simplified account, the Howard Government's take on ethics in government was a classic attempt to justify the discretionary use of its powers by reference to the renewal of public trust in it, as granted by electors at the election.

Mandates are tricky things, and that same election also returned a solid nongovernment majority in the Senate, which contested the right of any government to claim a mandate to govern. The Senate select committee that inquired into 'the certain maritime incident' reported adversely on the Howard Government's ethical performance (Select Committee on a Certain Maritime Incident, 2002). A subsequent Senate committee built on this initial inquiry and reported on the need for new legislation to bring greater accountability to bear on governments' use and abuse of the hidden power of ministerial staff (Finance and Public Administration References Committee, 2003). Both reports contain detailed examinations of government ministers' suspect conduct in abusing their powers over the Public Service and the responsibilities stipulated in the ministerial 
code of conduct not to deceive the public, and their obligation to correct any misleading public information, even in cases where there has been no deliberate intention to deceive.

The best investigative account of the 'children overboard' and related incidents is Marr and Wilkinson's Dark Victory (2003; compare with Weller, 2002). The book is a war story of sorts, detailing the armed resistance marshalled by the Australian Government against a perceived threat to the security of the country's sovereignty in the months leading up to a general election. It is also a political thriller, documenting the struggle within the government over deployment of military forces and the daring risk-management of the government's most astute political advisers, which won out against the traditional caution and risk-averseness of the professional military, particularly the Navy, which was committed as much to due process as to results.

The story begins in August 2001 with a Norwegian vessel, the Tampa, going to the rescue of 438 'illegals' - mainly Afghans fleeing the Taliban governmenton a sinking Indonesian vessel. They had been collected together in Indonesia by people smugglers intent on ferrying them to Australia. The Navy was instrumental in preventing the Tampa from docking at the Australian Territory of Christmas Island, and eventually shipping them to Nauru. Then in early October, the Navy rescued a further 223 people from another boat known as the 'SIEV 4'. The Howard Government portrayed both incidents as an attack, not just on Australian territory, but on sovereign Australian values. In the latter case, the 'SIEV 4 illegals' were not only unwelcome 'queue jumpers' but also untrustworthy and uncivilised manipulators of Australian assistance, even to the point - it was claimed - of throwing children overboard to get Australian authorities to accede to their demands for rescue and access to Australian care and custody. The claims were attributed to navy officials. Initially, these claims appeared correct, but the government made no mention of subsequent contrary defence 'doubts' or 'uncertainties' when the story wore thin.

These events dovetailed with John Howard's own personal experience in Washington on 9/11 when visiting the Bush Government. Less than a month later, as the 'war on terror' began, Howard called the 2001 election. The supposed attacks by 'boat people' became an election theme.

Marr and Wilkinson suggest that the 2001 electoral victory was marked by a stain of darkness: the Howard Government's deceit of the public by manipulating the truth about the significance of the increase in asylum-seekers during 2001, which culminated in the contortions of the 'children overboard' affair that helped consolidate electoral support for the government. The issue is, however, not really whether the government lied to voters but how it had already committed itself to playing the race card in the battle for public support. Howard's advisers 
may have been flattered to find how closely Marr and Wilkinson trace their skilful reinforcement of public sentiment about Australian vulnerability and the need for decisive leadership.

Marr and Wilkinson's story holds that the Howard Government's victory in 2001 is a case study in 'international best practice' political management, with Howard deserving recognition as Australia's master of the political art of misinformation. The 'v for victory' is overshadowed by the 'w for wedge', with Howard portrayed not in terms of international leadership but as a world leader of wedge politics: getting between political opponents and their natural supporters. Marr and Wilkinson do not hide their own personal views about the nastiness of the dark arts of deception practised by the Howard Government, epitomised by the singular achievement of retiring Defence Minister Peter Reith as the wizard of weasel words, as gifted in consolidating public support as he was in fracturing the confidence of the Labor Opposition.

Marr and Wilkinson are reporters, with no inclination to preach about solutions. The strength of the book is the authors' ability to mine the record, including through the use of freedom-of-information requests for defence evidence, and to relate the surface of daily events during the second half of 2001 to a deeper source of partisan calculation. If the devil is in the detail then their book is an account of the devil's workshop, showing a government tempting a people with the fear of terrorism. The authors' extensive use of the public record, particularly that generated by the Senate inquiry, is also supplemented by quite extensive interviews with most of the key players, to build up a richly layered picture of contemporary Australian governance. A strength of this account is the use of the court records relating to the Federal Court challenges against the government's alleged unlawful naval detention of asylum-seekers. Marr and Wilkinson show that there rarely is a 'whole of government' view on such basic things as legal duties, with important differences of professional opinion across defence, attorney-general's and central agencies.

For those who care little about the authors' advocacy of the rights of the refugees, Dark Victory still delivers fresh evidence about the norms of power in Australian government. The book profiles prominent figures, beginning with the Norwegian captain Arne Rinnan, then Commander Norman Banks of HMAS Adelaide, joined by close studies of the Howard ministry activists such as Philip Ruddock and Reith, followed by portraits of power illustrating the style of many bureaucratic chiefs. The book is a gallery of public managers, proving the point that systems are held in place by individuals, each with a distinctive sense of their professional role. Some of these officials participated in interviews with the authors and, in the case of Chris Barrie in particular, we are offered many quotes that help explain his delicate situation as Chief of the Defence Forces, acting as something of a powerboard with multiple leads connecting various 
military, bureaucratic and political agencies. Reading this book, one might conclude that no one person can play that role and expect to do justice to the interests of all concerned. There are bound to be power surges and blockages.

The bureaucracy deserves all the adverse attention Marr and Wilkinson give it. The Department of Immigration in particular comes in for an unsympathetic portrait. Attorney-General's gets a more flattering picture, more in tune with the authors' commitment to the high watermark of international obligations. The Department of Prime Minister and Cabinet is crucial but seems reduced here to two or three individuals, as though only they mattered. Defence features through the detailed and supportive account of the Navy's stubborn professionalism, to the point of getting up the nose of government loyalists. The civilian arm of defence gets off very lightly, as though Minister Reith knew how to manage well enough on his own. The great Canberra debate over ministerial staff and their accountability obligations passes without trace, implying that the Senate inquiry was chasing the tail of the wrong dog. The report of the Senate committee fails to get a mention, although the record of hearings is used frequently to good effect. All this is to say that Dark Victory is less about the weaknesses of defence intelligence about 'children overboard' and, in a backhanded compliment, more about the strengths of the Howard Government's strategy of 'truth overboard'. Dark Victory goes to the rescue of many truths left in the wake of the victorious Howard ship of state.

\section{Conclusion}

The above example illustrates my focus on professional relationships. It also illustrates my interest in political conduct that is, paradoxically, as corrupting as it is legal. Although this Australian practice is broadly consistent with current regulatory expectations, it falls far short of the regulative ideal I began with. The story is significant because it highlights the suspect ethical quality of so many political relationships within the Australian Government-including relationships of accountability. I have no magic box of regulatory mechanisms that can transform Australian or similar systems. Intent on bringing politicians closer to the task of self-regulation, I have contrasted prevailing tendencies with a regulative ideal. For all practical purposes, the prevailing tendencies are winning.

The 'children overboard' story does not turn on mundane conflicts of interest but on conflicts of constitutional responsibility, taking constitutional to refer not to the black letter of the law but to the norms of the different political offices 'constituting' a democracy. It is a classic example of the contestability of political ethics, testing in unprecedented ways the decency of many political 
relationships by politicians whose personal decency is not the question. It is a good example because it shows how political corruption advances under the cover of many disguises, including the disguise of 'politics as usual' (Uhr, 2001, particularly pp. 723-6). Putting Australian developments to one side, I conclude with some general lessons arising from this attempt to apply a professional ethics framework to democratic political ethics.

Most forms of professional or role ethics apply group norms to recognised individual practitioners of the profession in question. Politics is different, not only because the professional skill is unrelated to any specialised training and any associated professional academy, but also because the practice in question is fundamentally a shared or collective practice. This is so particularly in democratic regimes that quite properly pride themselves on participative public decision making and typically privilege the constitutional power of an elected assembly, even to the point of protecting the participation rights of non-government or opposition members. The collective nature of political professionalism extends beyond power-sharing within the ranks of elected representatives to include relationships between politicians and related professionals in public administration.

In this approach, professional political ethics refers to the widely distributed responsibility for determining appropriate standards relevant to these relationships of shared power and, in addition, to the collective resolution of disputed instances of unethical conduct. Particulars of responsible ethical conduct vary according to the nature of the political office under discussion: the precise ethical responsibilities varying with the power relationships managed by different political offices. This range of official responsibilities is itself subject to any formal constitutional constraints - a matter for the collective determination of the assembled professional politicians, acting under public oversight.

Thus, professional political ethics as used here refers to the collective determination of appropriate political conduct, which will be more ethically responsible when structured around due processes of fair and open political deliberation, in place of 'politics as usual'. Most existing systems of political ethics try to overcome the defects of 'politics as usual' by conferring special power on small groups of politicians comprising dedicated 'ethics' or 'privileges' committees with responsibility for investigating and adjudicating ethics infringements, judged against 'the rules' or codes of official conduct. My idealised model differs because it is a relationship-centred rather than a rulecentred approach. My approach is inevitably more uncertain and unpredictable than narrower forms of professionalism based on compliance with 'the rules'. But this very openness reflects, I think, the true nature of political ethics as a matter of political judgment-with disputes managed through collective 
political deliberation over appropriate relationships of power: representatives relating to their own offices and relating to other public offices sharing public power.

The implications of this focus on collective professionalism are considerable, including not least a surprising role for the public as the court of ultimate appeal. Democratic politics rests on the relationship between the professionals and the people; and the ethical quality of democratic politics depends in no small part on the ethics of the relationship between the people and their political representatives. Democracy can be thought to hold 'the people' in some sort of 'professional' regard, in that they have the responsibility (the final say) over the system of self-regulation we call democratic self-government.

\section{Acknowledgements}

My thanks to Patrick Dobel, Andrew Lister and Andrew Sabl for helpful comments on drafts of an earlier version of this paper (Uhr, 2006), reprinted here with revisions with the kind permission of the publisher. (See Uhr, 2010b, for another version of this argument.)

\section{References}

Bradley, F. H. (1962 [1876]). My station and its duties. In Richard Wollheim (Ed.), Ethical studies (2nd edn, pp. 160-213). Oxford: Clarendon Press.

Canadian Senate Ethics Officer. (2009-10). Annual report. Ottawa.

Coetzee, J. M. (1999). The lives of animals. Princeton: Princeton University Press.

Coetzee, J. M. (2003). Elizabeth Costello. New York: Knopf.

Coetzee, J. M. (2004). As a woman grows older. The New York Review of Books, 15 January, 13-20.

Coetzee, J. M. (2005). Slow man. New York: Knopf.

Coetzee, J. M. (2010). On the moral brink. The New York Review of Books, 28 October.

Cooper, Terry L., \& Wright, N. Dale(Eds). (1992). Exemplary public administrators: character and leadership in government. San Francisco: Jossey-Bass. 
Finance and Public Administration References Committee. (2003). Staff employed under the Members of Parliament (Staff) Act 1984. Canberra: The Senate.

Funk, Michael, \& Palm, Ralph. (2010). Irony and belief in Elizabeth Costello. In Anton Leist \& Peter Singer (Eds), J M Coetzee and ethics (pp. 337-56). New York: Columbia University Press.

Leist, Anton, \& Singer, Peter (Eds). (2010). J M Coetzee and ethics: philosophical perspectives on literature. New York: Columbia University Press.

Lodge, David (2003). Disturbing the peace. The New York Review of Books, 20 November.

Marr, David, \& Wilkinson, Marian. (2003). Dark victory. Sydney: Allen \& Unwin.

Select Committee on a Certain Maritime Incident. (2002). Report. Canberra: The Senate.

Sidgwick, Henry. (1967). History of ethics. London: Macmillan.

Uhr, John. (1998). Deliberative democracy in Australia. Cambridge: Cambridge University Press.

Uhr, John. (2001). Public service ethics in Australia. In Terry L. Cooper (Ed.), Handbook of administrative ethics (2nd edn, pp. 719-40). New York: Marcel Dekker.

Uhr, John. (2005). Terms of trust: arguments over ethics in Australian government. Sydney: UNSW Press.

Uhr, John. (2006). Professional ethics for politicians. In Denis Saint-Martin \& Fred Thompson (Eds), Public ethics and governance (pp. 207-25). Oxford: JAI Press.

Uhr, John. (2010a). Be careful what you wish for. In Jonathan Boston, Andrew Bradstock \& David Eng (Eds), Public policy: why ethics matters (pp. 79-97). Canberra: ANU E Press.

Uhr, John. (2010b). Modernised modes of government ethics. In Rainer Koch, Peter Conrad \& Wolfgang H. Lorig (Eds), New public service (pp. 329-44). Wiesbaden: Gabler Verlag.

Weber, Max. (1994 [1919]). The profession and vocation of politics. In Peter Lassman \& Roland Spiers (Eds), Max Weber: political writings (pp. 309-69). Cambridge: Cambridge University Press.

Weller, Patrick. (2002). Don't tell the prime minister. Melbourne: Scribe Books. Wood, James. (2003). A frog's life. London Review of Books, 25(20), 23 October. 